\title{
The Lara Phenomenon: Powerful Female Characters in Video Games
}

\author{
Jeroen Jansz • Raynel G. Martis
}

Published online: 2 February 2007

(C) Springer Science + Business Media, LLC 2007

\begin{abstract}
The content of games is an understudied area in social scientific research about video games. The purpose of the present study is to contribute to the understanding of the portrayal of gender and race in games. Previous research on game content has revealed that stereotypical masculine characters dominate video games and that those characters are generally White. Nowadays, quite a few video games have women in leading parts; Tomb Raider's Lara Croft is the prototypical example. In our study we investigated the so-called 'Lara phenomenon,' that is, the appearance of a competent female character in a dominant position. We also studied the portrayal of men and the race of both male and female characters. We did a content analysis on the introductory films of 12 contemporary video games. Our results show that female characters appeared as often in leading parts as male characters did. They were portrayed with a sexualized emphasis on female features. Most game characters belonged to the dominant White race, the heroes exclusively so.
\end{abstract}

Keywords Video games · Gender · Race · Stereotypes

Playing electronic games on a personal computer, a game console, a handheld device, or on the Internet is a relatively new, but increasingly popular, kind of mediated entertain-

J. Jansz $(\bowtie)$

The Amsterdam School of Communications Research, University of Amsterdam,

Kloveniersburgwal 48,

1012 CX Amsterdam, The Netherlands

e-mail: j.jansz@uva.nl

R. G. Martis

Faculty of Social and Economic Studies,

University of the Netherlands Antilles,

Willemstad, Curaçao, The Netherlands Antilles ment. The popularity of video games ${ }^{1}$ has arisen alongside the public's expression of serious concerns, in particular with respect to the effects of violent games (Grossman \& DeGaetano, 1999; Thompson, 2002). The scientific community has responded to these worries by executing dozens of studies about the effects of playing video games (e.g., Anderson \& Bushman, 2001; Sherry, 2001).

Far less attention has been devoted to game content. A small number of research projects have been done to analyze the way the world is represented in video games. Generally, the results of these content analyses show two things: first, the ubiquity of violence (Braun \& Giroux, 1989; Children Now, 2001; Dietz, 1998; Haninger \& Thompson, 2004; Smith, Lachlan, \& Tamborini, 2003; Thompson \& Haninger, 2001), and second, the stereotypic portrayal of gender and race - men hold dominant positions, women are submissive, and the majority of game characters are White (Beasley \& Standley, 2002; Brand, Knight, \& Majewski, 2003; Children Now, 2001; Dietz, 1998; Gailey, 1993; Provenzo, 1991; Ramírez, Forteza, Hernando, \& Martorell, 2002).

The purpose of the present study was to contribute to the tradition of research on the portrayal of gender and race in video games. Our first principal theme was gender. Anyone even slightly familiar with video games must have noted the recent advance of tough and competent female characters (Labre \& Duke, 2004). The massive popularity of female protagonist Lara Croft ever since the release of the first Tomb Raider game in 1996 seems to have paved the way for a woman who contrasts the dominant

\footnotetext{
'In this paper we employ 'video games' as shorthand that includes games that are played in arcades or on game consoles (e.g., Playstation2, X-box, GameCube and the Gameboy), computer games played on PCs, and on-line games on the Internet.
} 
stereotype (Kennedy, 2002; Rehak, 2003). In our study we tried to ascertain the existence of a so-called 'Lara phenomenon,' that is, the appearance of a tough, and competent female character in a dominant position. In addition, we studied the portrayal of men in order to learn if changes in the stereotype of women coincided with changes in the depiction of male characters. Our second theme was the race of game characters. We wanted to find out if contemporary game worlds were more racially diverse than was true earlier.

The present study entailed a descriptive analysis of the manifest content of a dozen contemporary video games. We did a systematic content analysis of the ways in which game characters were portrayed (Riffe, Lacy, \& Fico, 1998). In our analysis we used the character's role (for example, helper or villain) and position (for example, dominant or submissive) as the principal categories. This enabled us to investigate whether the 'Lara phenomenon' occurred in this set of games. In other words, we could ascertain in these contemporary games if female characters had a more competent and more powerful position than they had had in previous games. Obviously, we also had to establish the actual numbers of male and female characters, and whether they belonged to the racial majority or a racial minority. A last set of categories was concerned with the attire of the game characters, the shape of their bodies, and the prominence of relevant body parts like breasts and buttocks. Taken together, these categories enabled us to record general patterns in our set of 12 games and to evaluate our findings in relation to the earlier studies.

\section{Previous Research about the Portrayal of Gender and Race in Video Games}

Research on the portrayal of gender and race in entertainment media is particularly relevant because of the way in which media content is received by its users (Van Zoonen, 1994). Previous researchers from a variety of backgrounds have shown that media representations provide an important source for the construction of meaning in everyday life. People actively interpret what they have seen in the media to attribute specific meaning to, for example, their social relations or their identities (Brown, Dykers, Steele, \& White, 1994; Cohen, 2001; Gauntlett, 2002; Giles, 2002; Giles \& Maltby, 2004). In the case of video games, the reception of media content has a specific character because of the games' interactive nature. Players are largely in control of what they experience. They can change what happens in the game by some motor action via a controller, joypad, keyboard, or another kind of interface. When players stop interacting, the game falls dead (Grodal, 2003; Kiousis, 2002; Vorderer, 2000).
Interactivity has two distinct consequences for the reception of game content. First, enjoying a video game generally means that players are drawn into the represented world and become less aware of the mediated quality of the experience (Klimmt \& Vorderer, 2003). The resulting feeling of 'being there' is generally referred to as a state of "presence" (Lee, 2004). Presence conceivably may intensify the gamer's reception of game content in order to construct personal meaning. Second, interactivity may also have consequences for the gamer's identification with characters represented in the game. Many video games enable their players to enact identities in the most literal sense of the word. Gamers can actually 'be' their characters in a playful virtual reality. The opportunities for playfully probing identities are unique (Durkin, 2006; Jansz, 2005). For example, playing the part of Solid Snake in Metal Gear Solid2 means being in charge of his actions, which is fundamentally different from passively witnessing the actions of a hero on a movie or television screen.

Whereas many reception studies about traditional entertainment media underline the importance of identification with media characters (Brown et al., 1994; Cohen, 2001), research on identification with game characters still is in its infancy. In two studies, for example, it was found that the possibility to identify with a female protagonist contributed to girls' appreciation of video games (De Jean, Upitis, Koch, \& Young, 1999; Kafai, 1998). In another study, McDonald and Kim (2001) found that children identified quite closely with game characters and that these identifications had consequences for the development of their personalities. More recently, researchers found a relation between identification and narrative: Participants who played a game with a strong story line (Half-Life and Outlaws) reported a higher level of identification than did players of nonstory-based games (Doom 2 and Quake 2) (Schneider, Lang, Shin, \& Bradley, 2004).

The possible identification with video game characters provides an important rationale for research about game content, in particular about the kinds of roles and identities that are portrayed in games (Smith, 2006). Previous researchers generally have concentrated on gender identity, but a few studies also included racial identity. The research was often inspired by worries about the negative influence that one-sided portrayals, particularly stereotypes, might exert on (young) gamers (Children Now, 2001; Dietz, 1998; Gailey, 1993).

Braun and Giroux (1989) conducted one of the earliest studies about game content. They focused on depictions of violence in arcade games, but also observed that male characters were featured in almost $60 \%$ and female characters in only $2 \%$ of the arcade games. A more comprehensive study of the representation of gender in video games was published by Provenzo (1991). He 
focused exclusively on Nintendo games. He did not study the actual content of the games, but limited his research to a content analysis of the covers of the boxes of 47 games. He counted 124 human individuals in the cover illustrations. A vast majority of $92 \%$ was male (115 characters); only $8 \%$ was female ( 9 characters). Twentyfour percent of the men were represented in a dominant position, whereas none of the women were. By contrast, three of the nine women were portrayed in a submissive pose, whereas none of the men were (Provenzo, 1991). The results of Gailey's (1993) qualitative analyis of Nintendo games confirmed the pattern of dominant male and submissive female characters. A few women appeared as dangerous gang members who must be dealt with violently. 'Good' women, by contrast were shown as cute and unthreatening. A few years later, Dietz (1998) analyzed 33 games on the Nintendo and Genesis game-consoles. Thirty percent of the games did not have a female character in either the leading part or a supporting role. When the game did contain a female character, she was in $21 \%$ of the cases portrayed in a submissive, stereotypical position. Only $15 \%$ of the female characters attained the status of a hero in the game. The other female characters were princesses or wise old women, typically in a position to be released by the leading male character. Overall, Dietz noted, video games were dominated by masculine themes as, for example, action, war, violence, competition and sports. She added parenthetically that almost all characters were White (Dietz, 1998).

The emerging pattern was confirmed by the study commissioned by Children Now (2001). The researchers analyzed the content of 70 video games and found a wide range of traditional, if not stereotypical, men and women portrayed in the games. Overall, $64 \%$ of the games featured male characters, against $17 \%$ female. The male dominance increased to $73 \%$ among the player-controlled characters. Men were competitors in $47 \%$ of the games, and $50 \%$ of the women functioned as bystanders; they did not engage in the action. The female characters were generally "hypersexualized": their unrealistically large breasts and very small waists were emphasized through revealing clothing or partial nudity (Children Now, 2001). The characters were predominantly White, especially the heroes all of whom were White (Children Now, 2001). In the analysis of the game characters' clothing by Beasley and Standley (2002) a comparable gender distribution was found. They identified 597 characters in their selection of 47 games. Most characters were male (72\%); a minority of $14 \%$ was female, and $15 \%$ were of an undeterminable sex.

The Provenzo study was replicated and extended by Ramírez and his team (Ramírez et al., 2002). They studied the covers of $87 \mathrm{PC}$-games in addition to a set of 79 console games. The researchers coded 286 human characters in the cover illustrations. As in the Provenzo and Dietz studies, the vast majority was male $(239 ; 83 \%)$. Further, $71 \%$ of the male characters appeared in a dominant position, and $34 \%$ of the female characters in a submissive one. However, radical change had occurred among female characters: $50 \%$ of the women were portrayed in a dominant position, which is far more than the small group of female 'heroes' Dietz (1998) documented. Finally, five male characters were portrayed in a submissive position. A recent study of the prevalence of men and women on the covers of 72 video games underlined the dominance of male characters: $88 \%$ of the games had one of more human men on the cover, against $38 \%$ with one or more human women. Female characters were more often shown in partial nudity $(32 \%)$ than male characters were (20\%) (Smith, 2006).

Brand et al. (2003) analyzed the content of 130 games on a variety of aspects. They found that the vast majority $(71 \%)$ of lead characters were male. About $13 \%$ was female, and $16 \%$ had an unclear sex. They also concluded that the games were predominantly populated by stereotypical characters, and most of them were White. Haninger and Thompson (2004) reported that 72 of the 81 games in their sample $(89 \%)$ contained playable male characters, and 42 games contained playable female characters $(52 \%)$. The women in the game were significantly more likely to be depicted partially nude than the men were. Downs and Smith (2005) also studied sexual themes in video games. A content analysis of 60 games showed once more a dominance of male (86\%) over female characters (14\%). The women were generally portrayed in a hypersexual way: They were partially nude, or dressed in sexually revealing clothing, and featured with unrealistic body shapes. In terms of race, $50 \%$ of the game characters were White, followed by African (21\%), Asian (7\%), and Hispanic (3\%) (Downs \& Smith, 2005).

In conclusion, the results of previous studies indicate that many video game titles, published over a lengthy period of time, were dominated by male characters. Female characters appeared in submissive roles. It is also evident that most characters were White. The dominant trend should not blind us to the fact that the results of Ramírez et al. (2002) seem indicative of some change. They reported that $50 \%$ of the female characters held a dominant position, and they even found five male characters in a submissive position. The dominant trend, as well as the possible recent shifts results in the following question that guided our investigations:

RQ: how are characters in contemporary video games depicted with respect to gender and race, and how does this differ from depictions of gender and race in earlier video games? 


\section{Method}

The sample

Analyzing the content of video games is a complex enterprise (Smith, 2006). Video games are multilayered products that provide an enormous amount of content. The completion of a contemporary video game takes a well trained gamer about $20 \mathrm{~h}$ of playing. If researchers want to analyze the content of several games they must therefore be selective. Drawing a sample from the video games that are available on the market is a convenient way to reduce the number of games in an analysis. Most previous researchers used the games' popularity as a criterion for selection, by drawing a sample from games in top positions in sales charts. Our selection consisted of popular games too. The focus on successful titles prevented us from being occupied with games in a niche of the market that were possibly unusual in their portrayal of gender and race. However, we used additional criteria for inclusion, because selecting exclusively on the basis of popularity could easily result in a set of games with contents unsuitable for answering our research question. For example, sportsgames (for example, the FIFA soccer or NBA basketball series) and racing games (for example, Gran Turismo) are very popular, but their characters are generally male, and hardly developed in a role position.

The first additional criterion for inclusion was the diversity of the cast of characters with respect to gender and race. If we want to study the portrayal of men, women, and different races, these groups must obviously be present in the game. The second criterion was the narrative nature of the game: A story line was considered necessary because we wanted to determine both the role and position of the characters. For this reason, fighting games (or 'beat 'em

Table 1 The 12 video games in the analysis.

\begin{tabular}{lll}
\hline Title & Publisher & Year \\
\hline Charlie's Angels & Ubi Soft Entertainment & 2003 \\
Devil May Cry 2 & Capcom & 2003 \\
Enter the Matrix & Atari & 2003 \\
Final Fantasy X & Square Enix USA Inc & 2001 \\
GTA Vice City & Rockstar Games & 2002 \\
Metal Gear Solid 2: & Konami & 2001 \\
$\quad$ Sons of Liberty & & \\
Parasite Eve 2 & Square Electronic Arts & 2000 \\
Primal & SCE & 2003 \\
Shadowman 2: & Acclaim Entertainment & 2001 \\
The Second Coming & & \\
Silent Hill 3 & Konami & 2003 \\
Splinter Cell & Ubi Soft Entertainment & 2003 \\
Tomb Raider: & Eidos Interactive & 2003 \\
Angel of Darkness & & \\
\hline
\end{tabular}

ups,' for example, Tekken or Mortal Kombat) were not included. These games are almost always played as a sequence of person-to-person battles. The position of the characters (winner or loser) is totally dependent on the skills of the gamer. Some fighting games have a 'story mode' option, but the stories offered are very thin and lack development in role and position. The third criterion was practical: We selected games that were available on game console (Sony's Playstation2, and Microsoft's X Box), so that we could play the games rightaway without any need to update the hardware of our personal computers. Application of our criteria for inclusion resulted in a (non-random) sample of 12 games. The titles are listed in Table 1.

\section{Coding}

The analysis of the complete contents of 12 video games would still be an endless task, so a further selection was necessary. Previous content analyses used different strategies for selection. For example, Provenzo (1991) and Ramírez et al. (2002) limited their analyses to the illustrations on the cover-boxes of the video games. Beasley and Standley (2002) randomly selected a brief time sequence from the game. Both of those strategies have serious disadvantages. The cover illustrations are static pictures that cannot give detailed information about the role and position of the character within the game. The random selection of material has two disadvantages. First, the selection is dependent upon the game competence of the researcher (one researcher may have made more progress in the game than another) (Smith, 2006), and second, the selection may result in analysis of a sequence that is not informative (the time sample may, for example, result in a scene that is not characteristic at all for the game under analysis). We tackled the problems inherent in the strategies used earlier by following Brand et al. (2003) in selecting the introductory film of the video game as our data. This short film provides a clear outline of the game, its main characters, and the dominant storyline. It is, in other words, an adequate summary of the game, its purpose, and its content.

With our research questions about gender and race in mind, we decided to focus exclusively on the human characters. They were our units of analysis, which means that animals, monsters, and objects were not included. In each film we concentrated on the leading character (the protagonist) and one other character. We choose the human character that appeared first after the protagonist. In theory, this second character could be a supporter, but could also be an antagonist.

The introductory film was analyzed by means of a quantitative content analysis in the social scientific tradition (Riffe et al., 1998). We choose content analysis as our method for two reasons. First, our research is concerned 
with the portrayal of gender and race in general, that is, across different games. In the present study, we were not particularly interested in unique depictions in specific games. A quantitative description of a limited set of variables in several games is most likely to contribute to a general answer about the portrayal of gender and race. Second, we wanted to be able to relate the results of our research to earlier research on this topic. Our predecessors used content analyses to quantify and report their observations, and so did we (Beasley \& Standley, 2002; Brand et al., 2003; Children Now, 2001; Dietz, 1998; Downs \& Smith, 2005; Provenzo, 1991; Ramírez et al., 2002).

The variables used in our analysis were largely determined by our research question. In some cases our variables were equivalent to the ones used in earlier studies, in other cases we decided to be more specific. Our codebook consisted of the following variables.

Gender The decision about the game character's sex was based on his or her physical features.

Race Game characters were allocated to a particular race on the basis of their physical features, supplemented with the language they spoke. The earlier studies generally employed a rather gross distinction between a White group and a rather undifferentiated second group of People of Color. We differentiated between people from African descent, Latino/a, and Asian.

Role and position We followed the recommendation of Beasley and Standley (2002) to distinguish between the character's role and position. Stories use a limited set of roles, or dramatis personae. We distinguished eight roles. Four of them were equivalent with Propp's (1968) roles: Hero, Villain/Evil character, Helper, and Princess. We added the 'Tough' character as a fifth role. Like the Hero, the Tough character is central to the story, but it is not engaged in a mission and does not carry out beneficial deeds. We also added the roles of Mother, Housewife, and Victim. The characters were further scored with respect to their power position in the narrative of the game (dominant, equal, submissive).

Appearance A final set of variables was introduced because appearances are particularly relevant in the context of mediated stereotypes (Beasley \& Standley, 2002; Downs \& Smith, 2005; Gauntlett, 2002). We included both the character's attire and his or her physical properties. The variables were: Attire (sexy, ordinary), Body (heavy, normal, thin), Build (muscular, normal), Breasts (female characters only; large/emphasized, normal), and finally Buttocks (all characters; large/emphasized, normal).

\section{Procedure}

Two coders worked on this project. The first coder was one of the researchers (Martis), and the second was a woman with no background knowledge about video game research. We designed the first version of the codebook. After the coders discussed the codebook a slight revision of the definition of some variables was warranted. The second version of the codebook was used to test the agreement between the coders. They both scored the cinematic introduction of three games outside our selection of 12 (i.e., Devil May Cry, Maximo: Ghosts to Glory, and Rygar: the Legendary Adventure). In order to determine the percentage of agreement between the coders, Scott's Pi was calculated for all variables (Riffe et al., 1998). Almost all variables were in the range of .80 to .85 , which is generally considered to be good (Riffe et al., 1998). The variable 'Role' was the exception to the rule. It reached .75 , which still is acceptable. The overall agreement between the coders was high enough to embark on scoring the introductory films of the 12 selected video games. The coders each analyzed six games independently, and did not experience difficulties with the application of the codebook.

\section{Results}

The analysis of our selection of 12 video games resulted in a set of 22 characters. Two games did not have a second or supporting character in the introductory film: Splinter Cell focused exclusively on protagonist Sam Fisher, and Tomb Raider: Angel of Darkness focused exclusively on Lara Croft. The data are summarized in Table 2. Our analysis showed a dominance of male characters in the games. Thirteen of 22 game characters (about $60 \%$ ) were men. ${ }^{2} \mathrm{~A}$ difference appeared between characters who had a leading part in the game and those in a supporting role. Among the leading characters there was an equal gender distribution (six men; six women), but supporting characters turned out to be seven men (70\%) and three women $(30 \%)$.

The majority of characters in the video games were White ( 15 of 22 ; about $70 \%$ ). This pattern was repeated among the leading characters (75\% White). The supporting characters were a little more diverse, although the White race was again the largest group (60\%). Women in leading parts were almost exclusively White (five of six), and the male group was also dominated by White characters (four

\footnotetext{
${ }^{2}$ In order to enable comparisons between the variables, we also report the results in percentages. These must be interpreted with care, because they refer to small actual numbers. Our dataset did not meet the criteria for computing $\chi^{2}$. There were too many cells with an expected frequency less than 5 .
} 
Table 2 An overview of the results.

\begin{tabular}{|c|c|c|c|c|c|c|c|}
\hline \multirow[b]{2}{*}{ Variable } & \multirow[b]{2}{*}{ Category } & \multicolumn{3}{|c|}{ Leading character } & \multicolumn{3}{|c|}{ Supporting character } \\
\hline & & Male & Female & Total & Male & Female & Total \\
\hline \multicolumn{2}{|l|}{ Overall } & 6 & 6 & 12 & 7 & 3 & 10 \\
\hline \multirow[t]{4}{*}{ Race } & White & 4 & 5 & 9 & 5 & 1 & 6 \\
\hline & African & 1 & 1 & 2 & 1 & & 1 \\
\hline & Latino/a & & & & & 1 & 1 \\
\hline & Asian & 1 & & 1 & 1 & 1 & 2 \\
\hline \multirow[t]{3}{*}{ Position } & Dominant & 6 & 6 & 12 & 3 & 2 & 5 \\
\hline & Equal & & & & 1 & 1 & 2 \\
\hline & Submissive & & & & 3 & & 3 \\
\hline \multirow[t]{5}{*}{ Role } & Hero/in & 5 & 6 & 11 & 1 & 1 & 2 \\
\hline & Friend & & & & 3 & 1 & 4 \\
\hline & Villain & & & & 1 & 1 & 2 \\
\hline & Tough & 1 & & 1 & & & \\
\hline & Victim & & & & 2 & & 2 \\
\hline \multirow[t]{2}{*}{ Attire } & Sexy & 1 & 4 & 5 & & 1 & 1 \\
\hline & Ordinary & 3 & 2 & 5 & 6 & 2 & 8 \\
\hline \multirow[t]{3}{*}{ Body } & Heavy & & & & 1 & & 1 \\
\hline & Normal & 2 & 2 & 4 & 4 & & 4 \\
\hline & Thin & 4 & 4 & 8 & 2 & 3 & 5 \\
\hline \multirow[t]{2}{*}{ Build } & Muscular & 5 & 2 & 7 & 3 & 2 & 5 \\
\hline & Normal & 1 & 4 & 5 & 4 & 1 & 5 \\
\hline \multirow[t]{2}{*}{ Breasts } & Large & & 5 & 5 & & 2 & 2 \\
\hline & Normal & & 1 & 1 & & 1 & 1 \\
\hline \multirow[t]{2}{*}{ Buttocks } & Large & 2 & 5 & 7 & 1 & 2 & 3 \\
\hline & Normal & 4 & 1 & 5 & 6 & 1 & 7 \\
\hline
\end{tabular}

of six). The gender differences among the supporting characters were a little more substantial. The three women were White, Latina and Asian, but most men were White (five of seven; about $70 \%$ ).

It comes as no surprise that the leading roles, or protagonists, in the games held a dominant position with respect to other characters. It should be noted, though, that there was no difference in this respect between male and female leaders. The supporting roles showed an interesting contrast. First, female supporters held either a dominant or an equal position in the game. In other words, we did not observe a female character in a submissive position. Second, there were three male supporters $(43 \%)$ observed in a submissive position, one held an equal position, and three were dominant. The three men in supporting roles that had a submissive position functioned as a helper, or a friend, but not as a victim. In our sample of games, the two victims turned out to be male, and they held a dominant position in the game. This seems paradoxical, but it is not. Sometimes, a dominant character is seriously injured by a monster, for example in Shadowman 2: The Second Coming. Thomas Deacons is a muscular police officer who falls victim to a monster, but manages to escape.
Stereotypes are often linked to social positions and roles. With respect to the roles played in the games the hero role was observed in $60 \%$ of the cases (13 of 22 characters). This was followed by the friend or helper role (18\%), the villain $(9 \%)$, the victim $(9 \%)$, and the tough character $(5 \%)$. A result counter to traditional gender stereotypes is that all women in leading roles played the part of the heroine. Leading men were generally heroes, but Tommy Vercetti from GTA Vice City embodied the exception. He was scored as a tough character, rather than a hero, because his actions lack the positive connotation of heroism. Male characters in supporting roles were mostly friend or helper. The three supporting women played a diversity of roles: heroine, friend or helper, and villain.

The characters' clothing and physical features are important markers of gender and race. Sexy attire was mainly, though not exclusively, observed worn by female characters. The male figure Dante (Devil May Cry 2), for example, was presented in an explicit, sexy, and seductive outfit. The clothing of Lucia from Devil May Cry 2 and Jennifer from Primal confirmed the common stereotype about women's sexy attire. The game characters generally had well shaped bodies: a heavy body was the exception; most characters were depicted with normal, or thin bodies. A muscular build further emphasized the good shape. A majority of the male characters (8 of $13 ; 60 \%$ ) were portrayed with emphasized musculature, often in an extreme form. Our observations confirmed the importance that is generally attributed to breasts in a game context, especially in games designed for a 'mature' audience (Beasley \& Standley, 2002). Most female characters had large breasts (seven of nine; 77\%), as illustrated by Lara Croft and Jennifer (from Primal). Buttocks also were difficult to ignore. They were particularly emphasized among female characters (seven of nine; 77\%), but about $25 \%$ of the male characters also appeared with eye catching behinds.

\section{Discussion}

Our content analysis of 12 introductory films of video games confirms the trend observed by earlier researchers: games are dominated by male characters (Beasley \& Standley, 2002; Children Now, 2001; Dietz, 1998; Downs \& Smith, 2005; Haninger \& Thompson, 2004; Provenzo, 1991). Also, our results seem to indicate that the number of female characters in recent games is far larger than it was in earlier games. However, drawing this conclusion would be premature, because our sample may have been biased toward a higher prevalence of female characters: we did not draw a random sample but deliberately selected popular games with a diverse cast of characters. The sample we 
analyzed warrants though conclusions about changes in the position of male and female characters. Women and men were distributed equally in the class of leading characters (six women and six men) and women occupied a dominant position as often as men did. This is altogether different from the exclusively male leading characters in the studies by Provenzo (1991) and the Children Now (2001) team and quite different from the tiny percentage $(15 \%)$ of female heroes found by Dietz (1998). In addition, we found no submissive female characters at all. Women in our set of 12 games were equal to men, or they dominated them. This contrasts with the presence of submissive female characters in all other studies. Like Ramírez et al. (2002), we found a small number of submissive male characters. The example of Jennifer in Primal, who must embark on a journey to rescue her boyfriend Lewis, illustrates that men in contemporary video games can be victims who must be saved by a female character. Our results underline a tendency toward a different portrayal of female characters that was already observed in earlier research (Ramírez et al., 2002). We labeled this tendency the 'Lara phenomenon,' that is, the appearance of a strong, and competent female character in a dominant position.

The actual roles observed in the video games were very limited. Three of them corresponded with Propp's (1968) characters: hero, villain, and helper. In addition, we found depictions of victims, and tough characters. This result is surprising given the narrative nature of the games under analysis. One would expect more diversity in the roles portrayed. The physical features of male and female characters in our study were stereotypical, as found in four earlier studies (Beasley \& Standley, 2002; Children Now, 2001; Downs \& Smith, 2005; Haninger \& Thompson, 2004). The majority of male characters were depicted with extreme musculature. Female characters were generally portrayed with an emphasis on their buttocks and large breasts, scantily clad in hypersexualized dress.

The overrepresentation of White characters confirms the earlier observations by Dietz (1998) and the Children Now (2001) team. In both studies heroes were exclusively White, as was the case in our sample. Downs and Smith (2005) partly confirmed the dominance of White characters, although they also observed a rather large group (21\%) of characters of African descent.

The set of studies about game content in the past dozen years, including the project reported here, allows us to conclude that White characters predominantly populate video games. They are generally male. The roles men and women play in video games have changed in recent years: As leading characters, women hold a position they never held before. It seems that the representation of men has been less subject to change, although some of the male characters have recently held non-dominant positions. Gender stereo- types are particularly robust with respect to physical features. Men are still represented as hypermuscular characters and women as hypersexualized characters. In other words, quite a few women became leaders in the games, but they continue to be presented in a sexualized way. As a result, these powerful women are depicted as sex objects as much as their powerless predecessors were (Labre \& Duke, 2004).

The present study was limited in scope. We chose our set of 12 games according to pre-established criteria, rather than selecting a random sample from the games that were available on the market. This allowed us to add more detail to the results of previous research, in particular with respect to the role and position of the characters. In our study we solved the thorny issue of selecting material from games by focusing on the game's cinematic introduction. Analyzing the introduction is an adequate method, because it informs us about the covering story of the game, and the position of the characters in the narrative. At the same time, it is limited in the information it can provide. The introduction does not inform us about the (possible) changes in position that may occur further on in the game. For future research about game content, it seems advisable to follow the suggestion of Brand et al. (2003) to employ a more intensive (and expensive) method that includes both the introduction and a fragment from the game.

In our analysis, we followed the recommendation of Beasley and Standley (2002) to focus on the leading character. Generally, this is the primary, playable character. Actually playing the leading character provides options for identification. Given the abundance of hypermuscular men and hypersexualized women in the video games, it is not difficult to understand why the large majority of gamers are (young) men. The cast of many games enables male adolescents to enact extreme forms of masculinity that are unattainable in their daily lives (Jansz, 2005). These young men may also enjoy the objectification of women in video games: The virtual women may come to function as 'eye candy' for them. The situation is different for women. The gender stereotypes in video games probably are an important reason why (young) women play less than men do (Williams, 2006). Women who do play video games may experience contrasting consequences. On the one hand, they generally play disproportionately thin characters with exaggerated female characteristics that may teach them ideals about femininity and beauty that are possibly damaging to their health (Botta, 1999; Labre \& Duke, 2004; Smith, 2006). On the other hand, the Lara phenomenon may be empowering for female gamers. The female characters they are playing may look odd, but they are competent and occupy a powerful position in the virtual world of the video game. 
Acknowledgement The authors like to thank Alaiska Kock for her assistance with coding the video games. We are also grateful for the comments on an earlier version of this paper by the reviewers and the editor of Sex Roles.

\section{References}

Anderson, C. A., \& Bushman, B. J. (2001). Effects of violent games on aggressive behavior, aggressive cognition, aggressive affect, physiological arousal, and prosocial behavior: A meta-analytic review of the scientific literature. Psychological Science, 12, 353-359.

Beasley, B., \& Standley, C. T. (2002). Shirts vs. skins: Clothing as an indicator of gender role stereotyping in video games. Mass Communication \& Society, 5, 279-293.

Botta, R. A. (1999). Television images and adolescent girls' body image disturbance. Journal of Communication, 49, 22-41.

Brand, J., Knight, S., \& Majewski, J. (2003). The diverse worlds of computer games: A content analysis of spaces, populations, styles, and narratives. In M. Copier \& J. Raessens (Eds.), Level Up. Digital Games Research Conference (CD-ROM supplement). Utrecht: Universiteit Utrecht \& Digital Games Research Association.

Braun, C. M. J., \& Giroux, J. (1989). Arcade video games: Proximic, cognitive, and content analyses. Journal of Leisure Research, 21, $92-105$.

Brown, J. D., Dykers, C. R., Steele, J. R., \& White, A. B. (1994). Teenage room culture: Where media and identities intersect. Communication Research, 21, 813-827.

Children Now (2001). Fair play? Violence, gender, and race in video games. Retrieved May 5, 2003, from http:/www.childrennow. org/media/video-games/2001/\#race.

Cohen, J. (2001). Defining identification: A theoretical look at the identification of audiences with media characters. Mass Communication \& Society, 4, 245-264.

De Jean, J., Upitis, R., Koch, C., \& Young, J. (1999). The story of Phoenix Quest: How girls respond to a prototype language and mathematics computer game. Gender \& Education, 11, 207-223.

Dietz, T. L. (1998). An examination of violence and gender role portrayals in video games: Implications for gender socialization and aggressive behavior. Sex Roles, 38, 425-442.

Downs, E., \& Smith, S. (2005). Keeping abreast of hypersexuality: A video game character content analysis. Paper presented at the meeting of the International Communication Association, New York City (May).

Durkin, K. (2006). Game playing and adolescents' development. In P. Vorderer \& J. Bryant (Eds.), Playing video games (pp. 415-428). Mahwah, NJ: Erlbaum.

Gailey, B. (1993). Mediated messages: Gender, class, and cosmos in home video games. Journal of Popular Culture, 27, 81-97.

Gauntlett, D. (2002). Media, gender, and identity. London, UK: Routledge.

Giles, D. C. (2002). Parasocial interaction: A review of the literature and a model for future research. Media Psychology, 4, 279-305.

Giles, D. C., \& Maltby, J. (2004). The role of media figures in adolescent development: Relations between autonomy, attachment, and interest in celebrities. Personality and Individual Differences, 36, 813-822.

Grodal, T. (2003). Stories for eye, ear, and muscles: Video games, media, and embodied experiences. In M. J. P. Wolf \& B. Perron (Eds.), The video game theory reader (pp. 129-155). London: Routledge.

Grossman, D., \& DeGaetano, G. (1999). Stop teaching our kids to kill. New York: Crown.
Haninger, K., \& Thompson, K. M. (2004). Content and ratings of teen-rated video games. Journal of the American Medical Association, 291, 856-865.

Jansz, J. (2005). The emotional appeal of violent video games for adolescent males. Communication Theory, 15, 219-241.

Kafai, Y. (1998). Video game designs by girls and boys: Variability and consistency of gender differences. In J. Cassell \& H. Jenkins (Eds.), From Barbie to Mortal Kombat. Gender and computer games (pp. 90-111). Cambridge, MA: MIT.

Kennedy, H. W. (2002). Lara Croft: Feminist icon or cyberbimbo? Game Studies, 2, 1-12.

Kiousis, S. (2002). Interactivity: A concept explication. New Media and Society, 4, 355-383.

Klimmt, C., \& Vorderer, P. (2003). Media psychology 'is not yet there': Introducing theories on media entertainment to the presence debate. Presence, Teleoperators and Virtual Environments, 12, 346-359.

Labre, M. P., \& Duke, L. (2004). Nothing like a brisk walk and a spot of demon slaughter to make a girl's night: The construction of the female hero in the Buffy video game. Journal of Communication Inquiry, 28, 138-156.

Lee, K. M. (2004). Presence, explicated. Communication Theory, 14, $27-50$.

McDonald, D. G., \& Kim, H. (2001). When I die, I feel small: Electronic game characters and the social self. Journal of Broadcasting and Electronic Media, 45, 241-258.

Propp, V. (1968). Morphology of the folktale (2nd ed.; Trans. Lawrence Scott). Austin, TX: University of Texas Press.

Provenzo, E. F. (1991). Video kids: Making sense of Nintendo. Cambridge, MA: Harvard University Press.

Ramírez, S. U., Forteza, B. R., Hernando, J. L. O., \& y Martorell, S. G. (2002). El rol de la figura femenina en los videojuegos. Edutec. Revista Electrónica de Tecnología Educativa, 15. Retrieved 14 May, 2005 from http://edutec.rediris.es/Revelec2/ revelec15/santos.htm.

Rehak, B. (2003). Mapping the bit girl: Lara Croft and the new media fandom. Information, Communication, \& Society, 6, 477-496.

Riffe, D., Lacy, S., \& Fico, F. (1998). Analyzing media messages. Mahwah, NJ: Erlbaum.

Schneider, E. S., Lang, A., Shin, M., \& Bradley, S. D. (2004). Death with a story: How story impacts emotional, motivational, and physiological responses to first-person shooter video games. Human Communication Research, 30, 361-375.

Sherry, J. L. (2001). The effects of violent video games on aggression: A meta-analysis. Human Communication Research, 27, 409-432.

Smith, S. L. (2006). Perps, pimps, and provocative clothing: Examining negative content patterns in video games. In $\mathrm{P}$. Vorderer \& J. Bryant (Eds.), Playing video games (pp. 57-75). Mahwah, NJ: Erlbaum.

Smith, S. L., Lachlan, K. \& Tamborini, R. (2003). Popular video games: Quantifying the presentation of violence and its context. Journal of Broadcasting and Electronic Media, 47, 58-76.

Thompson, C. (2002). Violence and the political life of video games. In L. King (Ed.), Game on: The history and culture of videogames (pp. 22-32). London, UK: Barbican.

Thompson, K. M., \& Haninger, K. (2001). Violence in E-rated video games. Journal of the American Medical Association, 286, 591598.

Van Zoonen, L. (1994). Feminist media studies. London, UK: Sage.

Vorderer, P. (2000). Interactive entertainment and beyond. In D. Zillmann, \& P. Vorderer (Eds.), Media entertainment (pp. 21-37). Mahwah, NJ: Erlbaum.

Williams, D. (2006). A brief social history of game play. In P. Vorderer \& J. Bryant (Eds.), Playing video games (pp. 197-212). Mahwah, NJ: Erlbaum. 